\title{
1. Trends and patterns in intra-ASEAN migration
}

\section{Aiko Kikkawa and Eric B. Suan*}

\section{INTRODUCTION}

Regional integration has played an essential role in driving economic and social development in many regions of the world. It generates growth by expanding markets and boosting productivity through the exchange of new ideas and production technologies. A deeply interconnected region can gain considerable efficiency by sharing natural and human resources. Through this process, development becomes more inclusive and contributes to important non-economic benefits such as regional security and political stability (ADB 2008).

A key vision of the Association of Southeast Asian Nations (ASEAN) is establishing a globally competitive region with a single market and production base - one that embraces the free flow of goods, services, investment, and skilled labor. With the establishment of the ASEAN Economic Community (AEC) in December 2015, the region has advanced its agenda and taken on new challenges to achieve deeper regional cooperation and integration. The AEC has four objectives: (i) creating a single market and production base; (ii) increasing competitiveness; (iii) promoting equitable economic development; and (iv) further integrating ASEAN within the global economy. ASEAN members have already invested considerably in building cross-border physical infrastructure and harmonizing market regulations that facilitate trade and investment.

ASEAN has succeeded in catalyzing large inflows of foreign direct investment (FDI) globally to create a highly integrated base for production and trade. The region has become one of the world's fastest-growing investment destinations - accounting for $18.5 \%$ of total global inflows in 2015 compared with just 5\% in 2007 (ASEAN Investment Reports). Its combined gross domestic product (GDP) nearly doubled from 2007, while average GDP per capita grew by almost $80 \%$ - to over $\$ 5,000$. ASEAN dialogues and summits have contributed to the region's relative peace and security despite its diversity in cultures, languages, and levels of economic development. 
The movement of people and labor contributes to efficient and productive use of human capital and catalyzes transfer of knowledge across the region. It is an integral part of the AEC and includes policies that ease the movement of tourists, students, and skilled professionals, among others. There is a growing desire within the region to take a more proactive role to facilitate and foster labor mobility - especially in attracting, retaining, and circulating ASEAN's skilled workforce - as many members become more knowledge-based economies that require greater innovation. In addition, aging populations and changing demographics will necessitate more efficient use of human resources through regional collaboration.

This introductory chapter provides an overview of the latest trends and patterns of the mobility of people in ASEAN against the backdrop of regional economic integration. The next two sections describe the dynamics of ASEAN labor migration and how it relates to the overall framework and regional integration policies. Subsequent sections explore the possible roles labor mobility will play in the post-2015 AEC. Some policy recommendations and suggestions for future research close the chapter.

\section{ASEAN MODEL OF REGIONAL INTEGRATION AND ITS LABOR MOBILITY FRAMEWORK}

ASEAN economic integration process has been market-driven and outward-oriented (Hill and Menon 2014). While deepening cooperation and economic integration between members remains its primary goal, ASEAN also actively promotes relations with other countries and regions - primarily the PRC, Japan, and the Republic of Korea (ASEAN+3), and the United States (US). A key strategic goal of ASEAN - which spans the gamut from high-income to upper and lower middle-income countries, along with several low-income members - is to create a regional market with an investment climate that attracts regional and global FDI.

The ASEAN regional economic integration strategy consists of multilayered initiatives which aim to achieve high standards of connectivity - be it physical infrastructures, institutional and policy arrangements (trade/ investment agreements and standardized administrative procedure) or people-to-people interactions (in education, tourism, and skills mobility). The Master Plan on ASEAN Connectivity-for 2011-2015, currently updated through 2025 - defines benchmarks and goals for each initiative.

The overall results to date have been impressive. ASEAN intraregional trade grew from $\$ 68.7$ billion in 1995 to $\$ 276$ billion in 2016, largely intermediary goods feeding regional value chains. Figure 1.1 compares the bilateral flows of exports between ASEAN members in 1995 and 

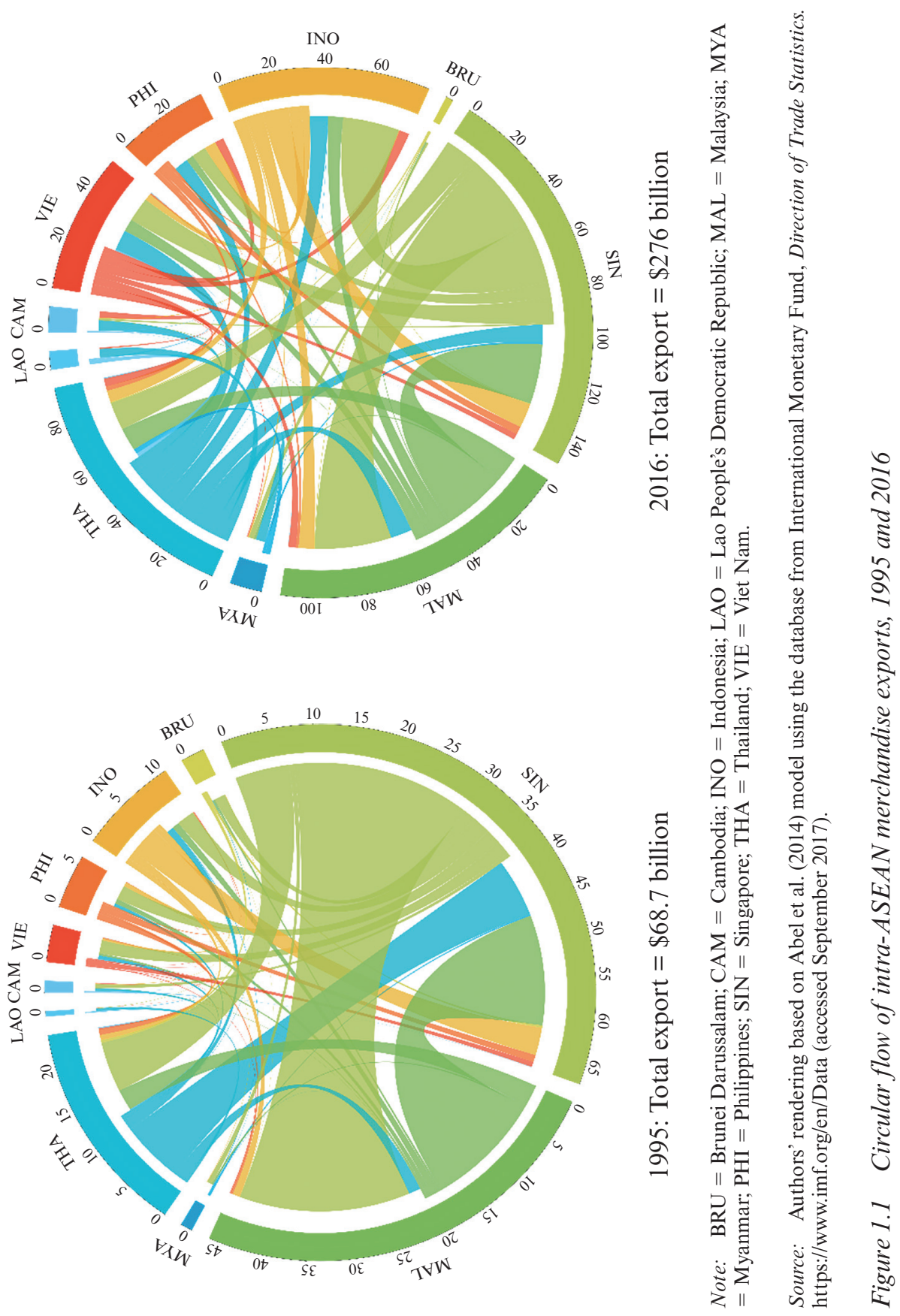
2016. Each strip or line represents the proportionate volume and direction of exports from origin (outer circle) to destination (inner circle). Early on, transactions among Malaysia, Singapore, and Thailand dominated intra-ASEAN trade flows. In 2016, however, regional export shares are more evenly spread across members. The region developed tightly knit production and trade linkages and emerged as one of the most integrated economic regions in the world (ADB 2017).

As for the intra-ASEAN share of goods and services trade (either for imports or exports), it remained below $30 \%$ of annual trade volumes during 1970-2016 (Figure 1.2). Major trading partners outside ASEAN are the PRC, Japan, and the US. In the meantime, ASEAN attracted large FDI inflows from advanced economies, and they accounted for $18.5 \%$ of total global FDI inflows in 2015. ASEAN's well-integrated yet open regionalism approach sets itself apart from the more institutionalized, formal regional economic groups such as the EU, offering exclusive privileges to its members.

\subsection{ASEAN Initiatives on Labor Mobility}

For many years, ASEAN approached labor mobility mostly as an extension of open trade and investment - more specifically through the promotion of services trade ("Mode 4," or the "movement of natural persons"), which deals with the temporary entry of skilled persons. This group of people consists of intra-cooperate transferees, investors, and highly skilled workers. Members have signed at least three relevant ASEAN-wide agreements - even if to date none has entered into force.

The ASEAN Framework Agreement on Services (AFAS) was signed in 1997, and it is quite similar to the General Agreement on Trade in Services (GATS) in terms of the coverage (ADBI 2014). However, when quantifying the level of liberalization using the Hoekman Index ${ }^{1}$ - which quantifies the level of openness - AFAS (as of 2012) would be more open on trade in services than GATS if enacted (Fukunaga and Ishido 2015).

The two other agreements were designed specifically to promote intraASEAN mobility of people. The ASEAN Framework Agreement on Visa Exemption allows visa-free travel for ASEAN nationals across the region for up to 14 days. The ASEAN Agreement on the Movement of Natural Persons was signed in 2012 to further liberalize services trade across the region (Fukunaga and Ishido 2015). Again, these agreements have never been implemented. ASEAN itself admits that "progress on freer mobility of skilled labor in ASEAN has been limited" (ASEAN 2015). 


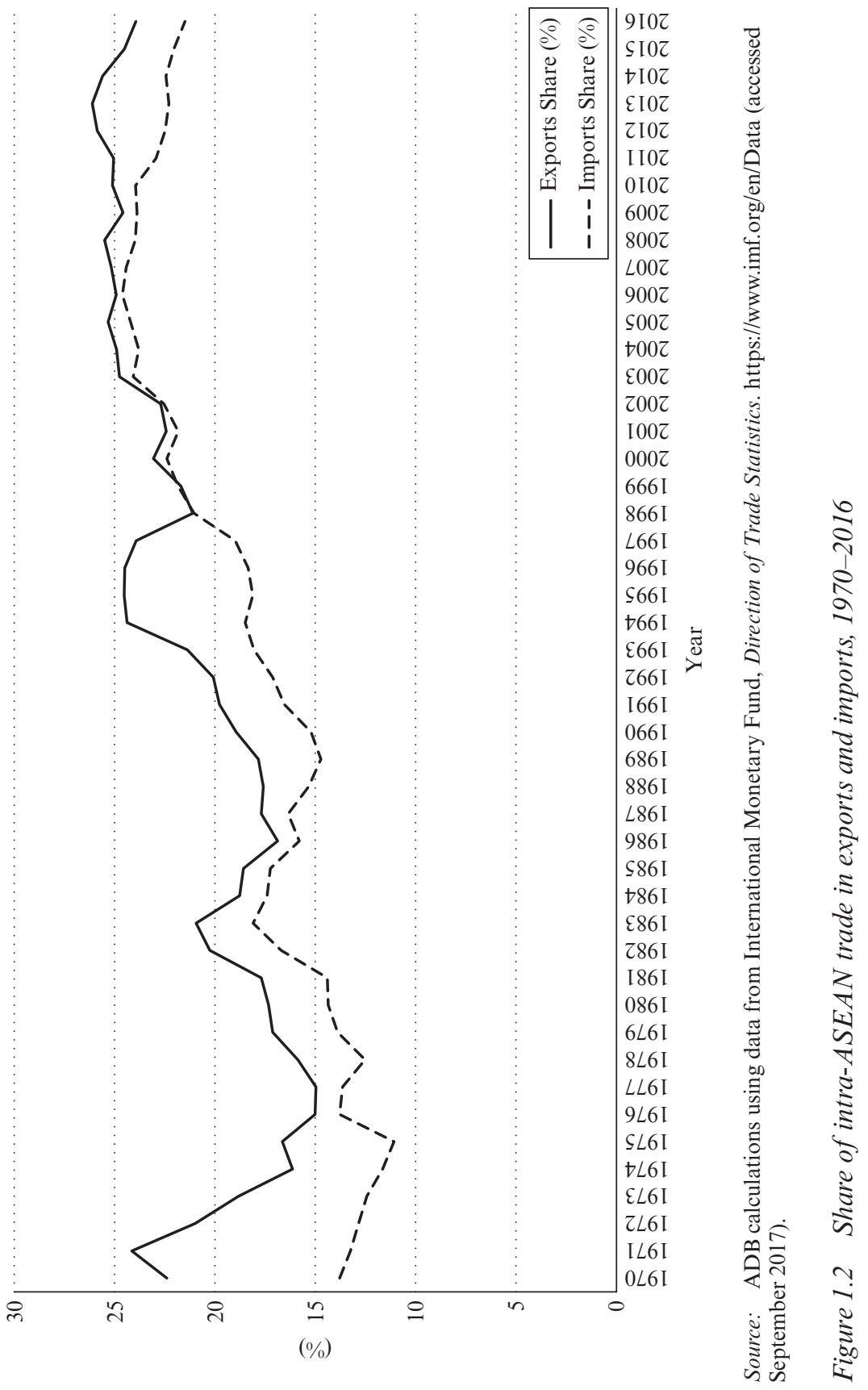




\subsection{Migrant Workers in ASEAN}

Despite the stalled ASEAN skills mobility initiatives, the number of people and labor moving across ASEAN substantially increased over recent decades. Intra-ASEAN migration ${ }^{2}$ tripled from 2.1 million in 1995 to 6.9 million in 2015 (Figure 1.3), with its share of total migrants into ASEAN rising from $57.6 \%$ in 1995 to $70.0 \%$ in 2015 . ASEAN consists of countries with net migrant inflows-Brunei Darussalam, Malaysia, Singapore, and Thailand - and net outflows - Cambodia, Indonesia, the Lao People's Democratic Republic (Lao PDR), Myanmar, the Philippines, and Viet Nam. There intra-regional flows come largely within the purview of bilateral arrangements between source and host countries and labor and immigration laws of host countries, rather than ASEAN-wide initiatives.

Figure 1.4 plots the patterns of intra-ASEAN migration in 1995 and 2015-using United Nations (UN) bilateral migration stock data. Each strip or line represents the proportionate volume and direction of migration (in stock) from source (outer circle) to host (inner circle). It is clear that intra-ASEAN labor mobility is concentrated within the Greater Mekong Subregion (GMS) - migrants from Cambodia, the Lao PDR, and Myanmar to Thailand - as well as the Indonesia-Malaysia route and migration from Malaysia to Singapore.

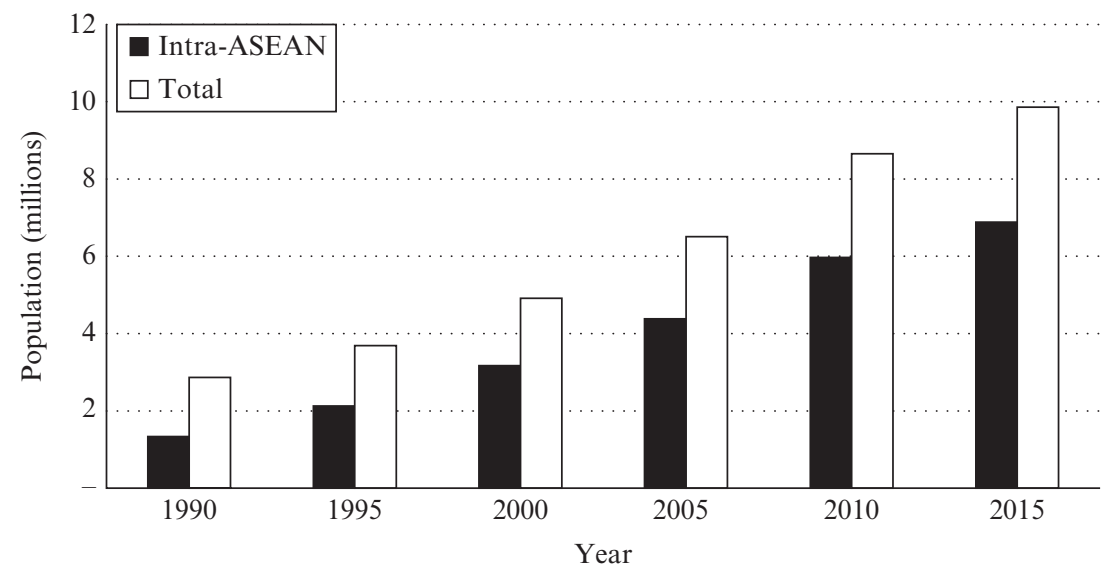

Source: United Nations Department of Economic and Social Affairs, Population Division, "International Migrant Stock: The 2015 Revision" (United Nations database, POP/DB/MIG/Stock/Rev.2015). Accessed 1 May 2016 at www.un.org/en/development/desa/ population/migration/data/estimates $2 /$ index.shtml.

Figure 1.3 Migrant stock in ASEAN by region of origin, 1990-2015 

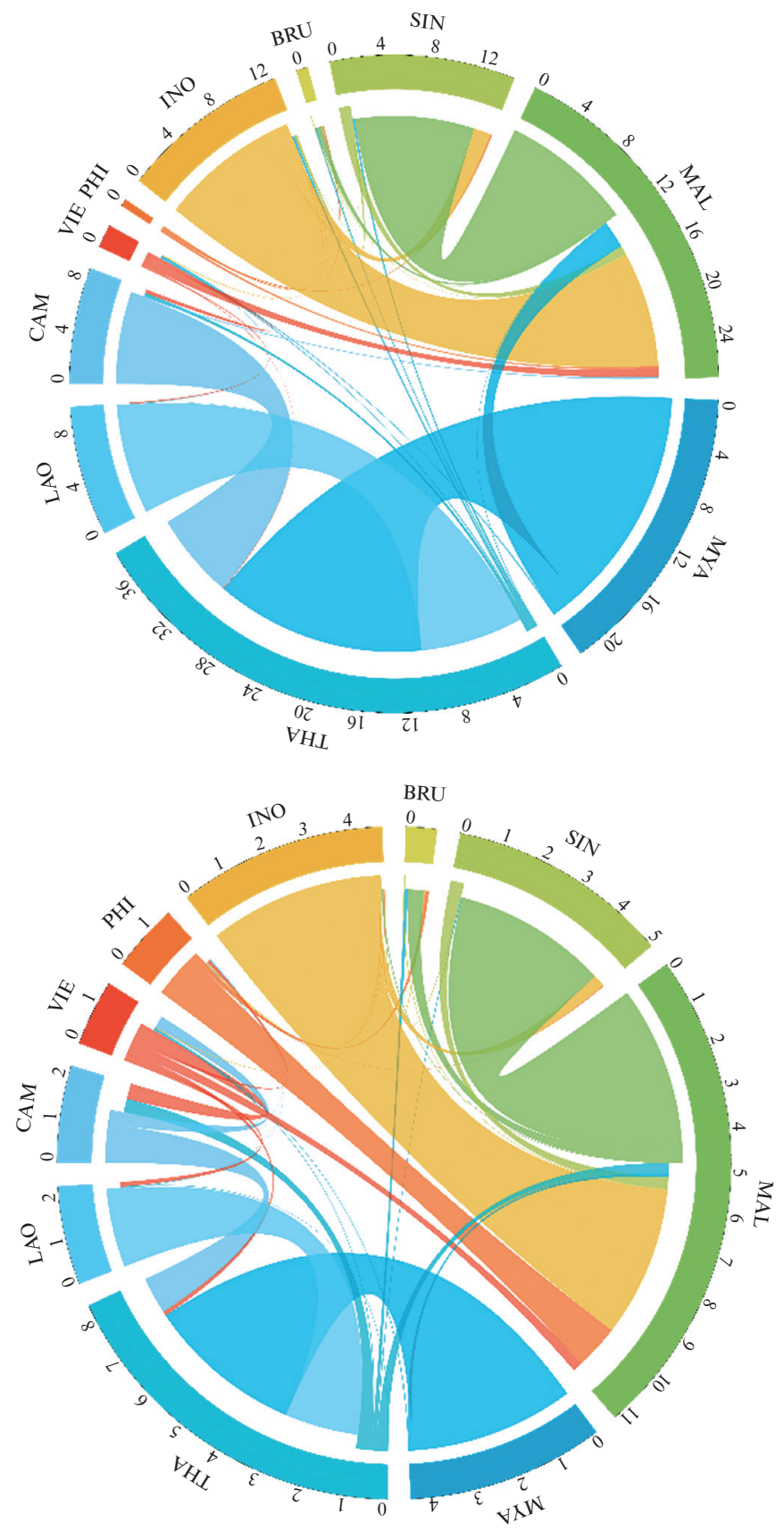

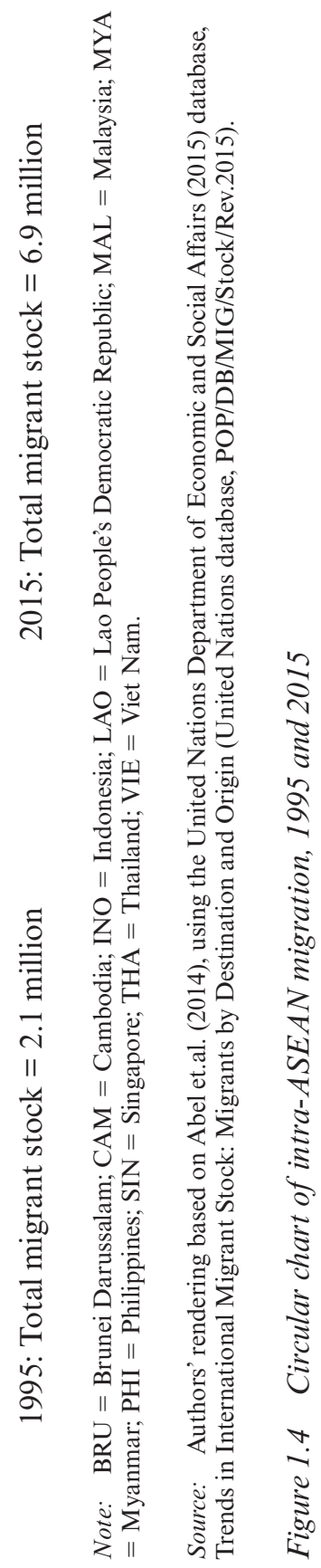


Over the years, there is a modest proportional expansion of GMS labor toward Thailand where more jobs are available in agriculture, fisheries, construction, and domestic services, with the limited opportunities in Myanmar pre-economic reform driving many workers searching for jobs outside the country. Labor movement from Indonesia to Malaysia and from Malaysia to Singapore, while increasing in volume, saw its relative share decline. The official labor migration from Indonesia to Malaysia was frequently suspended during the period due to bilateral disputes. Singapore is already host to many foreign residents ( $46 \%$ of its current population) and has limited scope to expand its migrant intake given its topography.

It is perhaps surprising that the Philippines - one of the largest migrant source countries globally_plays a very limited role in intra-ASEAN migration. The share of Viet Nam is also small and declining. The majority of migrants from the Philippines and Viet Nam live and work outside ASEAN_primarily in the US, the Middle East, and other Asian countries/territories. Even then Figure 1.4 likely underestimates labor mobility, particularly between the Philippines and Malaysia. UN data show the number of Filipinos in Malaysia declined from 123,116 in 1995 to 21,732 in 2015. By contrast, Philippine Overseas Employment Administration (POEA) data show that the departure of workers from the Philippines to Malaysia increased from 6,768 in 1995 to 26,199 in 2015. The UN data may not consistently provide an accurate picture of labor mobility where irregular or short/circular migration is rampant or when a country reports statistics based on its own definition of international migrants. ${ }^{3}$ Irregular migration is a sensitive topic for several ASEAN members and is rarely addressed, despite the significant implications it brings to the border regions.

While the amount of intra-ASEAN migration has grown substantially over the years, the major patterns of intra-ASEAN labor mobility have not changed dramatically. This contrasts with the trade (export) patterns discussed earlier - where networks and links have deepened across ASEAN. A major difference between goods/services trade and the mobility of people is that the former is more reciprocal than the other. Mutual dependency appears through trade, for example, in intermediary goods whereas the wage differentials tend to dictate the direction and the volume of the labor mobility.

Interestingly, large unidirectional traffic of people within ASEAN are primarily managed by the host and origin governments. For example, Thailand has a separate memoranda of understanding (MOU) with the government of Cambodia, the Lao PDR, and Myanmar, specifying procedures to formalize labor migration. Malaysia also has MOUs with several major migrant source countries - such as Indonesia - to strengthen 
labor migration governance and transparency. Singapore largely sets its labor migration regulations unilaterally with its neighboring ASEAN countries Unlike the trade agreements where multilateral schemes are widely adopted, labor migration accords remains bilateral in most cases.

\subsection{Wage Differentials and Remittances}

The primary factor driving large cross-border and intra-ASEAN labor migration is the persistent, uneven levels of economic development across the region. The average monthly wage in Thailand is three times above neighbors Cambodia and the Lao PDR (Figure 1.5). The same is true between Malaysia and Indonesia. Singapore's high wage premium attracts workers at all skill levels from the region and beyond.

Intra-ASEAN worker remittances reached $\$ 7.8$ billion in $2016(12.7 \%$ of the total $\$ 61$ billion in remittances from the world to ASEAN). Intraregional remittance shares are high in Cambodia, the Lao PDR, Malaysia, Myanmar, and Malaysia, ranging from $56.7 \%$ to $68.0 \%$ (Figure 1.6). The overall intra-ASEAN share remains low because its three largest remittance earners - the Philippines, Indonesia, and Viet Nam-receive most from regions outside ASEAN.

\subsection{Intra-ASEAN Skilled Worker Migration}

The shortage of publicly available data makes it difficult to evaluate the scale of high-skilled worker migration within ASEAN. There is no integrated source of data on labor migration by skill or education levelalthough ongoing initiatives should fill the gap. ${ }^{4}$ Patching together available data and information shows skilled worker migration is only a small portion of overall intra-ASEAN migration (Orbeta 2013). Its volume and share, however, is likely increasing over time.

Singapore hosts a large number of professionals and skilled workers, but comprehensive data on foreign workers by skill and nationality are not publicly available. According to the UN, there are 1.1 million Malaysians living in Singapore, with over 200,000 estimated to be tertiary-educated (World Bank 2014, p. 36). Data from the Singapore Nursing Board show an accelerating rate of health professionals migrating to Singapore from other ASEAN countries such as the Philippines and Malaysia in recent years (Table 1.1).

Aside from Singapore, the share of highly skilled migrants - defined as managers, professionals, and technicians (and associated professionals) in ASEAN countries remains low (Table 1.2). Brunei Darussalam has a somewhat higher share at $18 \%$, but this is not the case in other ASEAN 


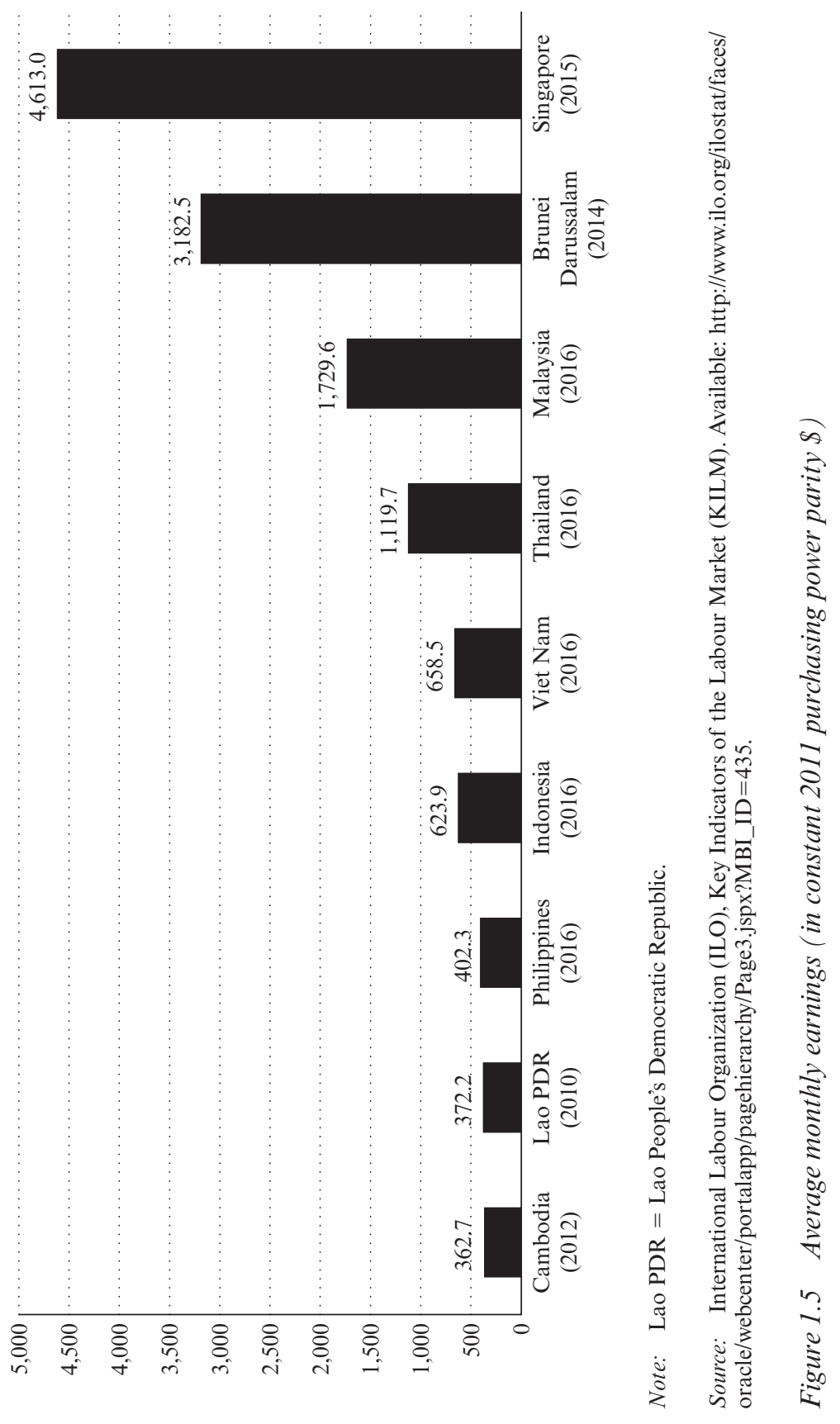




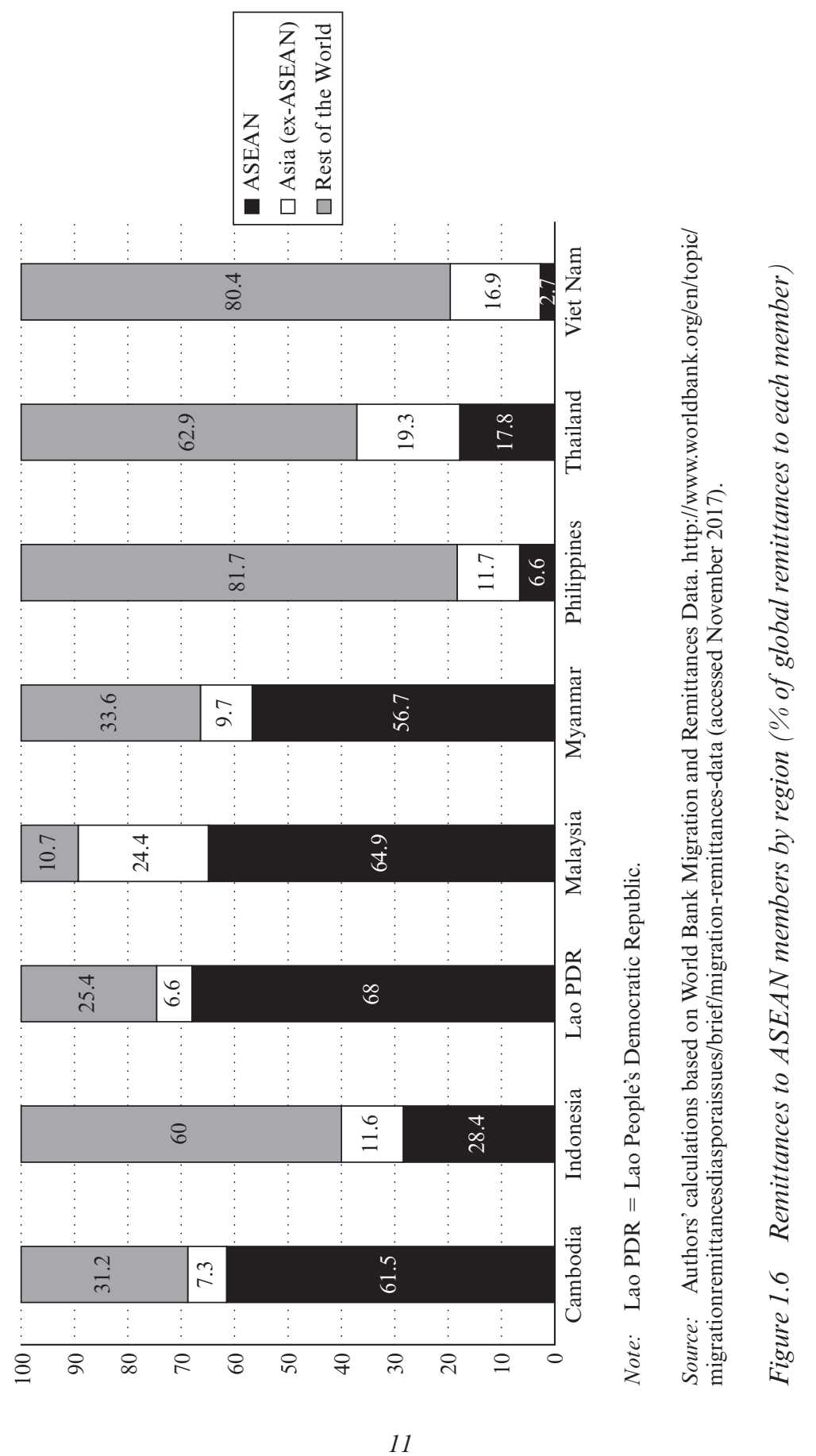


Table 1.1 Registered nurses in Singapore by citizenship, 2010 and 2016

\begin{tabular}{lrrrrrr}
\hline Nationality & 2010 & $\begin{array}{c}\% \text { of } \\
\text { Total }\end{array}$ & $\begin{array}{c}\% \\
\text { Foreign }\end{array}$ & 2016 & $\begin{array}{r}\% \text { of } \\
\text { Total }\end{array}$ & $\begin{array}{r}\% \\
\text { Foreign }\end{array}$ \\
\hline Foreign & 3,399 & & 100.0 & 9,679 & & 100.0 \\
India & 220 & 1.0 & 6.5 & 544 & 1.7 & 5.6 \\
Malaysia & 468 & 2.2 & 13.8 & 2,230 & 7.1 & 23.0 \\
Myanmar & 165 & 0.8 & 4.9 & 742 & 2.3 & 7.7 \\
Others & 208 & 1.0 & 6.1 & 266 & 0.8 & 2.7 \\
Philippines & 1,760 & 8.2 & 51.8 & 4,942 & 15.6 & 51.1 \\
PRC & 578 & 2.7 & 17.0 & 955 & 3.0 & 9.9 \\
Singapore & 18,176 & 84.2 & $\ldots$ & 21,936 & 69.4 & $\ldots$ \\
Total & 21,575 & 100.0 & & 31,615 & 100.0 & \\
\hline
\end{tabular}

Note: $\quad$ PRC $=$ People's Republic of China.

Source: Singapore Nursing Board, Annual Reports, 2010, 2016. http://www.healthprofessio nals.gov.sg/docs/librariesprovider4/publications/annual-report-2010_1.pdf; http://www.health professionals.gov.sg/docs/librariesprovider4/publications/snb-annual-report-2016.pdf.

countries. There is no additional information to know how many of these positions are held by ASEAN professionals.

\subsection{Mutual Recognition Arrangements}

One important step of ASEAN in facilitating regional skill mobility is the Mutual Recognition Arrangement (MRA) initiative, which establishes common skill and qualification recognition schemes in the region. To date, MRAs have been signed for seven qualifications including engineering services, nursing, architectural services, tourism, medical practitioners, dental practitioners, and accounting services. There is a framework arrangement for the mutual recognition of surveying qualifications, an important step towards the signing of an MRA in surveying. Each MRA has its own implementation modality and has made varying levels of achievement to date (Mendoza and Sugiyarto 2015). MRAs with the most visible progress are on architectural and engineering services, where recognized professionals have begun to register at the ASEAN level. As of March 2018, the ASEAN Chartered Professional Engineers Register had 2,876 engineers listed and the ASEAN Architect Register listed 475 architects (Figure 1.7). The accountancy MRA is trying to follow these examples. Preexisting recognition standards, such as the Asia-Pacific Economic Cooperation (APEC) Engineer initiative contributed to the relatively quick establishment of the ASEAN engineer framework (Mendoza et al. 2016). 


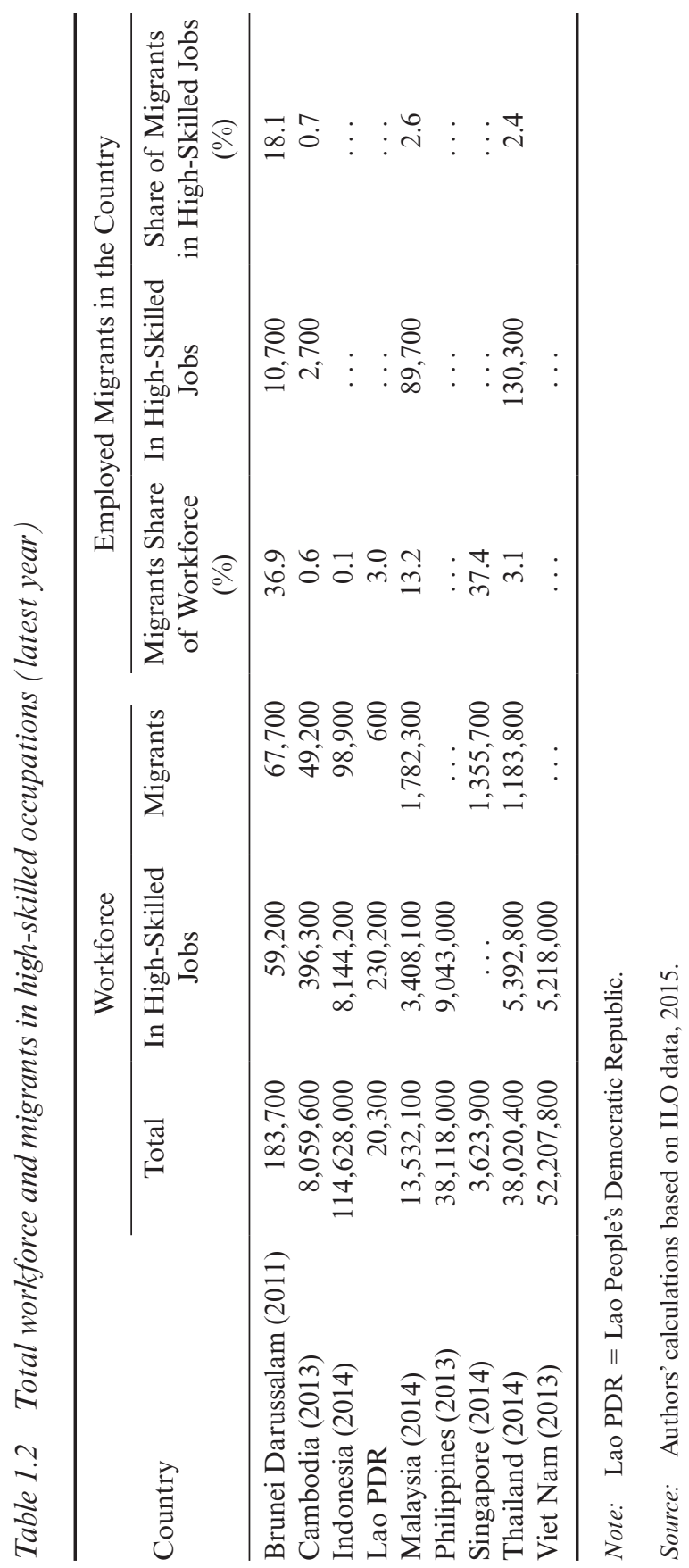




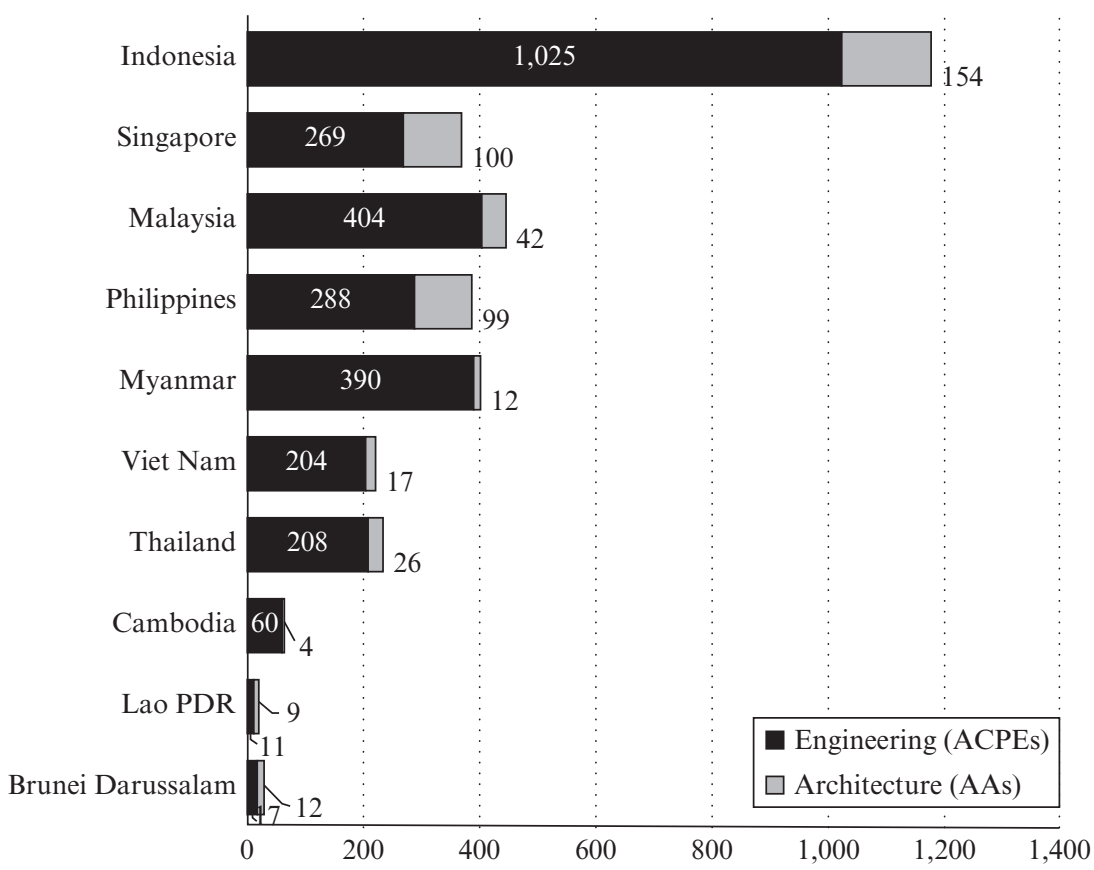

Note: $\quad$ ACPE $=$ ASEAN Chartered Professional Engineers; AA $=$ ASEAN Architect Register; Lao PDR = Lao People's Democratic Republic.

Source: ASEAN Secretariat, ILO (2017).

Figure 1.7 Mutual recognition arrangements (professionals registered as of March 2018)

Competency standards and curricula for tourism professionals were drafted and a registration system launched in 2016. In contrast to other MRAs, tourism initiatives are largely private sector-driven and use a relatively straightforward credential-recognition process. The medical and health care-related MRAs have seen limited progress in drawing up common standards; and corresponding changes in national laws and regulations are needed to allow ASEAN certified professionals to work across ASEAN.

The MRA implementation in ASEAN has been either slow or stymied in some sectors. Various challenges and obstacles stand in the way. For skills with a recognition scheme in place, there are few workers registered and certified (see, for example, Chapter 9). Coordination between respective occupational and professional groups within industries must 
be strengthened to raise awareness that MRA certifications exist and to increase the pool of ASEAN-chartered professionals. Professional organizations covered by MRAs in all ASEAN counties are encouraged to build and maintain functional databases of nationally certified professionals. The next important step is to explore ways to link MRA schemes to specific job opportunities to promote skilled labor mobility. Finding ways to tailor and design admission policies based on a positive circularity principle seems to be the key. National professional associations tend to be cautious. Proving ASEAN-wide circular skilled labor mobility helps reduce the fear of regional competition and contributes to a more dynamic growth of ASEAN skills mobility.

For skill categories still trying to formulate standardized ASEAN recognition schemes, an appropriate - and non-political — task force should be established. The task force should objectively propose to government agencies how best to standardize recognition schemes-based on facts and research. As mentioned, one of the key reasons behind the slow implementation is the worry that MRAs will open the door to cheap skilled labor and threaten local jobs. Therefore, it is critical to introduce skill upgrading opportunities, and compensatory measures that enhance competitiveness and strengthen social safety nets alongside MRA implementation.

Before expanding MRAs to other skills, there is a need to clearly define guidelines on how foreign qualifications will be recognized and certified. The lessons learned from ongoing ASEAN MRA exercises should be compiled and analyzed to help develop a single platform for professionals from a wider discipline to be certified as ASEAN professionals. Synergies can be built by exchanging experiences in building the ASEAN Qualifications Reference Framework and the Committee currently tasked to harmonize domestic qualification frameworks.

\section{OUT-MIGRATION OF ASEAN WORKERS TO OTHER REGIONS}

While intra-ASEAN migration has grown substantially over time, the fact remains that $60-70 \%$ of ASEAN's international migrants reside outside the region (Figure 1.8). Some 41\% (5.5 million) live in other Asian host countries-including the 3.6 million based in "West Asia" (the Gulf region). Another 37\% (5.0 million) are in North America, with 13\% (1.7 million) in Europe (Figure 1.8). The top 5 host countries for ASEAN migrants are the US (20\%), Saudi Arabia (9.8\%), Australia (4.4\%), Canada (4.2\%), and the United Arab Emirates (4.1\%). 


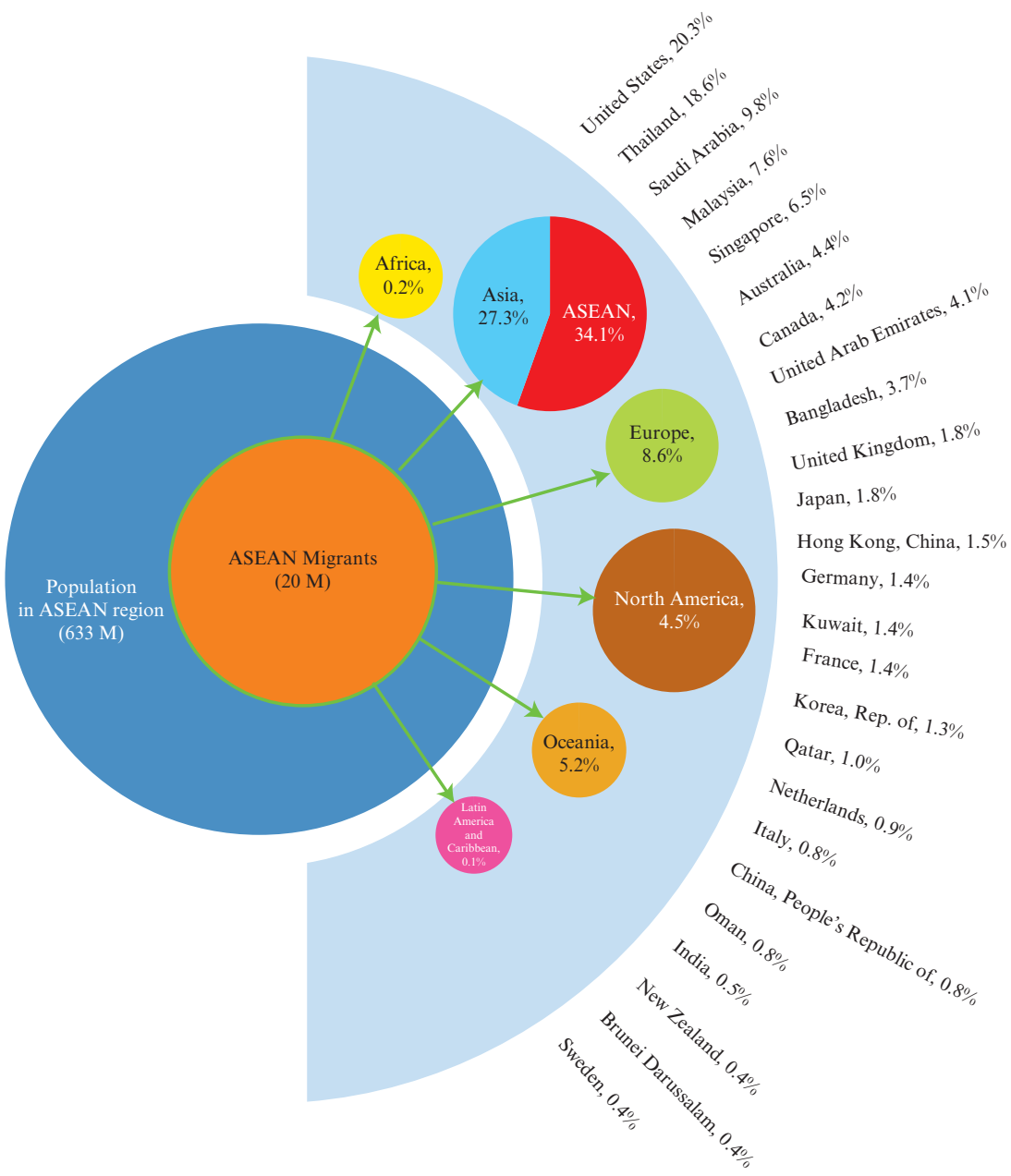

Note: $\quad \mathrm{M}=$ million people.

Source: Authors' calculations using the United Nations Department of Economic and Social Affairs database (2015), Trends in International Migrant Stock: Migrants by Destination and Origin (United Nations database, POP/DB/MIG/Stock/Rev.2015).

Figure 1.8 ASEAN migrants outside the region, 2015 
Table 1.3 Tertiary-educated migrants in OECD members by country of origin, 2000-2001 and 2010-2011

\begin{tabular}{lrrc}
\hline Origin & $2000-2001$ & $2010-2011$ & $\begin{array}{c}\text { \% Change: } \\
\text { 2000-2010/11 }\end{array}$ \\
\hline Brunei Darussalam & 3,358 & 5,854 & 74.3 \\
Cambodia & 36,456 & 52,552 & 44.2 \\
Indonesia & 117,035 & 153,884 & 31.5 \\
Lao PDR & 37,469 & 52,035 & 38.9 \\
Malaysia & 101,998 & 169,471 & 66.2 \\
Myanmar & 25,170 & 42,090 & 67.2 \\
Philippines & 889,072 & $1,545,164$ & 73.8 \\
Singapore & 46,327 & 74,658 & 61.2 \\
Thailand & 74,427 & 156,920 & 110.8 \\
Viet Nam & 348,141 & 539,099 & 54.9 \\
ASEAN & $1,679,453$ & $2,791,727$ & 66.2 \\
Total (all countries) & $18,097,377$ & $31,133,150$ & 72.0 \\
\hline
\end{tabular}

Notes: $\quad$ ASEAN $=$ Association of Southeast Asian Nations; Lao PDR $=$ Lao

People's Democratic Republic; OECD = Organisation for Economic Co-operation and

Development.

Data refer to people aged 15 and above.

Source: Batalova et al. (2017).

\subsection{ASEAN Skilled Workers in Organisation for Economic Co-operation and Development (OECD) Countries}

The number of skilled ASEAN migrants in OECD countries is increasing rapidly. Those with tertiary education (all ages) grew $66 \%$ between 2000 and 2010 (to 2.8 million) (Table 1.3). Tertiary educated migrants from Thailand more than doubled, followed by Brunei Darussalam (a $74.3 \%$ increase), the Philippines (73.8\%), and Myanmar (67.2\%). The strong networks of Filipino migrants (55\% of total ASEAN migrants) and those from Viet Nam (21\%) are a powerful pull factor (Batalova et al. 2017). ASEAN countries will have to increase their attractiveness as a work base if they are to compete with OECD countries in attracting the talent. 


\section{POST-2015: BRAIN CIRCULATION FOR A MORE "COMPETITIVE AND INNOVATIVE ASEAN"}

With the establishment of the AEC in December 2015, ASEAN members are now guided by the second ASEAN Economic Community (AEC) Blueprint 2025, which lays out a broader set of goals and initiatives to further promote regional cooperation and integration. The Blueprint recognizes that ASEAN countries face new challenges and an economic agenda. The first and foremost challenge is to achieve a "competitive, innovative, and dynamic" economy across the region. For many members, this means making the transition to high-income status. This requires substantially improved productivity and efficiency; and to build an economic and business environment conducive to innovation.

ASEAN is entering the phase of economic development where skills mobility plays an increasingly critical role in entering and moving up global value chains. Mobility also helps the process of production specialization by fostering agglomeration of people and skills-where a critical mass of professionals creates communities and networks; and information, ideas, and talents are exchanged (World Bank 2009, Chapter 5). Local and foreign investors and businesses will likely demand more active involvement of the government and use the AEC to attract talent to the region.

The lack of skilled workers is a real potential bottleneck to deepening the AEC. A study suggests that as many as 25.9 million skilled jobs in Cambodia, Indonesia, the Lao PDR, and in the Philippines, Thailand, and Viet Nam can remain unfilled in 2025 (ILO and ADB 2014). For most countries, this means more than half the jobs requiring skilled workers will not find candidates with appropriate skills. Acceleration of global competition for talent may require ASEAN to achieve deeper economic integration under the AEC umbrella to share a skilled workforce. Rising wages across ASEAN may attract some overseas workers to return and local workers to stay. Yet, by 2030 - with labor markets worldwide continuing to liberalize - ASEAN members are likely to face increased out-migration of skills to countries offering even higher wages (Walmsley et al. 2013).

Demographic change is another major factor in shaping ASEAN labor supply and mobility in the coming decades. Today, many ASEAN countries enjoy a demographic dividend-where labor force growth outpaces that of total population. But by 2020 , ASEAN overall will begin to witness a decline in the workforce. The unique feature of ASEAN is that its members have a variety of demographic profiles. Figure 1.9 shows when each ASEAN country starts and ends its demographic dividend. ${ }^{5}$ Five countries have ended or will soon end the period of workforce expansion 


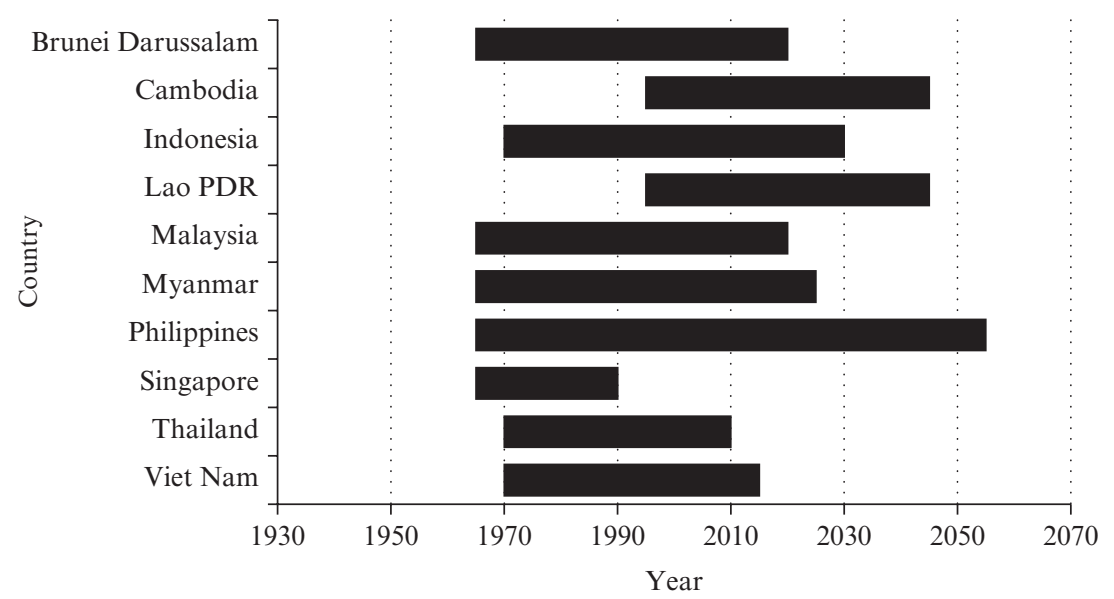

Note: $\quad$ Lao PDR $=$ Lao People's Democratic Republic.

Source: United Nations Population Division, Department of Economic and Social Affairs, World Population Prospects, the 2017 Revision. https://esa.un.org/unpd/wpp/ (accessed August 2017).

\section{Figure 1.9 Actual and projected demographic dividends among ASEAN members}

(Brunei Darussalam, Malaysia, Singapore, Thailand, and Viet Nam), with three members expected to benefit from the demographic dividend for decades to come (Cambodia, the Lao PDR, and the Philippines). The two most populous countries in ASEAN, Indonesia and the Philippines, the source of many overseas workers, will continue to see their workforce grow until around 2030. These diverse population profiles also echo the need for greater intra-ASEAN labor mobility across many skill levels. It is a core tenet of a better-functioning AEC.

Despite the range of opportunities and challenges facing members in promoting regional labor mobility, the AEC Blueprint 2025 continues to rely on mobility of skilled persons through MRAs and attracting more business visitors (provision A5 of the Blueprint, page 10). As discussed, MRAs have yet to tangibly increase professional worker mobility and that the process in many sectors has yet to receive support from the professional associations. While it is important to continue the MRA process and broaden sector coverage, bolder measures will be needed to ensure ASEAN workers at all skill levels can meet future labor demand and increase the region's competitiveness. Two issues should be tackled: (i) attracting skilled international ASEAN migrants to bring their skills and 
knowledge back (or circulate) to the region; and (ii) easing worker mobility across various skill levels within the AEC.

\subsection{Attracting Skilled Workers to the AEC}

ASEAN remains a net exporter of human capital - many of them skilled. There is clear evidence of the exodus of skilled labor, but it also means there is a significant pool of trained, experienced ASEAN citizens outside the region that can contribute to the AEC's success. ASEAN countries may want to consider collectively introducing measures to attract skilled workers back to the region, in addition to existing programs individually run by several members to encourage their nationals to return home.

Countries worldwide have made various attempts to retain existing skilled personnel and reverse the "brain drain" by offering incentives. Program trials and errors have amassed substantial knowledge on how to run these programs more effectively (Agunias and Newland 2012). It is increasingly clear that interventions must be targeted. For example, a recent evaluation of the Malaysian Returning Expert Program shows that the program is effective in targeting those with job offers (but not for those who are undecided), suggesting that the approach to provide "last mile support" to aspiring returnees is effective in helping them decide to return (Del Carpio et al. 2016).

ASEAN members may also want to cooperate in welcoming back the skilled migrant diaspora as investors and entrepreneurs - aside from considering them a skilled workforce. Most important is creating a favorable environment for doing business. India's example in information technology (IT)-related business built a formidable reserve of trained workers that attracted diaspora investment. To encourage this kind of positive cycle in the long run, policies that "retain" skilled workers at home (preventing them leaving) should be discouraged because they become disincentives for skill acquisition and limit access to global networks that provide technology, investment, and trade opportunities (Clemens 2015).

\subsection{Sharing ASEAN's Talent}

ASEAN can move beyond MRAs to catalyze labor mobility by introducing more active policies that facilitate movement across a wider array of skills. For example, workers with regional qualifications may be given priority in processing job applications matching the skill or industry that best benefits members with different demographic profiles and labor market conditions. The scheme can be devised so as to maximize efficiency in sharing talent. 
The need to promote circulating workers goes beyond the realm of just the highly skilled. As demographics shift across the region, so will ASEAN's surplus and deficit labor markets. The demand for semi- to lower-skilled workers is already high and may increase to meet the growing need in services, health care, and household services - a major benefit to working families across ASEAN. The scarcity of semi-skilled workers may in fact be more acute as workers' educational attainment will increase rapidly in the coming years. The growing senior populations in East Asia and other developed countries are opening large migration opportunities for middle- and low-skilled workers from ASEAN. And this can exacerbate labor shortages across ASEAN.

If the exodus of semi- and lower-skilled migrants from ASEAN continues, migrants from outside ASEAN might fill the gap. Increasing numbers of migrants from South Asia are already servicing Singapore and Malaysia. And others may join to satisfy the increasing demand. ASEAN countries will need to decide whether to develop extra-ASEAN labor migration programs, either individually or jointly.

The ASEAN Declaration of Protection and Promotion of the Rights of Migrant Workers was adopted at the 2007 ASEAN Summit. It calls for countries to strengthen measures to ensure a decent working environment for all migrant workers in the region, across all skill levels. As a follow-up to the Declaration, the Consensus of the ASEAN Instrument on the Protection and Promotion of the Rights of Migrant Workers was adopted in October 2017 at the ASEAN Leaders Summit. ASEAN members are now committed to drafting an action plan to protect all migrant workersincluding those in "irregular situations." These frameworks could open the door for greater collaboration in dealing with ASEAN labor mobility more comprehensively.

\section{CONCLUSION AND POLICY RECOMMENDATIONS}

ASEAN economies have succeeded in deepening economic integration both regionally and globally through trade, investment, and financewhich has provided a source for development and growth in the region. There is equally a dynamic flow of labor across ASEAN and from ASEAN to the world. But, as ASEAN itself acknowledges, tangible results in facilitating labor mobility remain limited. Most policies remain in the hands of individual countries. Achieving intra-ASEAN labor mobility requires strong political will across government levels, and cooperation from employers and professional organizations. Achieving the AEC 
Blueprint 2025 of a highly integrated and cohesive economy depends on these commitments.

With many ASEAN members confronting the middle-income challenge of transiting to high-income status - coupled with aging and demographic changes - there is a growing need to encourage labor mobility beyond skilled mobility and service trade facilitation. There will be growing demand from businesses and investors to attract, retain, and circulate human resources across the region.

The time is therefore ripe for ASEAN to become more active in promoting labor mobility to better balance surplus and deficit labor markets and thus boost growth across the region. While encouraging the completion and utilization of existing MRAs, ASEAN can begin to explore how lessons learned can be collated to create an umbrella scheme of skill recognition and relevant Regional Qualification Framework. It is critical to connect these qualifications to the actual mobility in sectors or occupations that benefit all members.

It is also worth considering expanding the scope and framework within ASEAN to cover labor mobility for all skill levels-including semi- and lower-skilled workers. Demand for these workers - who comprise most intra-ASEAN labor mobility and work in sectors like agriculture, fisheries, construction, caregiving, and household work - is expected to rise globally, while supply is expected to decline. ASEAN countries should encourage one another to work together to develop a regional human resource development plan and strategy. It can objectively assess the adequacy of supply and come up with measures to fill possible gaps - also considering extra-ASEAN human resource and technological innovation.

To better inform the policy process, it is critical that data on migration, migrant labor, and the region's skilled workforces be collected and made available publicly. Lack of data makes it difficult to carry out relevant research to answer key policy questions - including labor market outlook projection, and estimating the net gain or loss from labor mobility for each country and the AEC itself.

Facilitating labor mobility - when viewed from the broad perspective of the ASEAN Community and its long-term objectives - will not only contribute to growth by raising productivity, but also make that growth more inclusive and equitable (one of the four AEC objectives). UN Sustainable Development Goal (SDG) 10 also states that the facilitation of orderly, safe, regular, and responsible migration and mobility of people can reduce inequality within and among countries. It is in this spirit that ASEAN members can step up their effort to promote connectivity, including that of people and its workforce. 


\section{NOTES}

* The authors would like to thank Paul Mariano for providing the circular flowcharts (Figures 1.1 and 1.4).

1. The Hoekman Index maps out the degree of liberalization in services trade under four "ASEAN+" frameworks. See Ishido (2011) for a more detailed discussion on the tool.

2. International migrants of ASEAN origin residing in other ASEAN member countries. The United Nations (UN) defines international migrants as those residing abroad for more than one year. Cross-checking national data of ASEAN members shows that international migrants in ASEAN are largely labor migrants, while others include students, family members, and displaced persons.

3. For more discussion on migration data needs in ASEAN see section 4 of Batalova et al. (2017).

4. For example, see ILO ASEAN Labor Migration Statistics, http://apmigration.ilo.org/ asean-labour-migration-statistics.

5. Demographic dividend refers to economic gains emanating from rapid growth of the working-age population. As much as 33\% of the growth in East Asia from 1965 to 1990 can be attributed to favorable demographics (Bloom et al. 2000).

\section{REFERENCES}

Abel, G., R. Bauer, N. Sander, and J. Schmidt (2014), 'Visualising Migration Flow Data with Circular Plots'. Vienna Institute of Demography Working Papers Austrian Academy of Sciences. https://www.oeaw.ac.at/fileadmin/subsites/ Institute/VID/PDF/Publications/Working_Papers/WP2014_02.pdf.

Agunias, D.R. and K. Newland (2012), Developing a Road Map for Engaging Diasporas in Development: A Handbook for Policymakers and Practitioners in Home and Host Countries. Geneva: IOM/MPI.

Asian Development Bank (2017), Asian Economic Integration Report 2017: The Era of Financial Interconnectedness. How Can Asia Strengthen Financial Resilience? Manila: ADB. https://www.adb.org/publications/asian-economic-integration-report-2017.

Asian Development Bank (2008), Emerging Asian Regionalism: Partnership for Shared Prosperity. Manila: ADB. https://www.adb.org/sites/default/files/publi cation/159353/adbi-emerging-asian-regionalism.pdf.

Asian Development Bank Institute (2014), ASEAN 2030: Toward a Borderless Economic Community. Tokyo: ADBI. https://www.adb.org/publications/asean2030-toward-borderless-economic-community.

Association of Southeast Asian Nations (2015), ASEAN Economic Community Blueprint 2025. Jakarta: ASEAN. https://asean.org/?static_post=asean-economic -community-blueprint-2025.

Batalova J., A. Shymonyak, and G. Sugiyarto (2017), Firing Up Regional Brain Networks: The Promise of Brain Circulation in the ASEAN Economic Community. Manila: ADB. https://www.adb.org/publications/regional-brain-networks-asean.

Bloom, D., D. Canning, and P. Malaney (2000), 'Population Dynamics and Economic Growth in Asia'. Population and Development Review 26, Supplement: Population and Economic Change in East Asia: pp. 257-290.

Clemens, M. A. (2015), 'Smart Policy towards High-Skilled Emigrants', IZA World of Labor. https://wol.iza.org/articles/smart-policy-toward-high-skill-emigrants/long.

Del Carpio, X., C. Ozden, M. Testaverde, and M. Wagner (2016), 'Global Migration 
of Talent and Tax Incentives: Evidence from Malaysia's Returning Expert Program'. Policy Research Working Paper No. 7875, World Bank Group. http:// documents.worldbank.org/curated/en/881411478027078856/pdf/WPS7875.pdf.

Fukunaga, Y. and H. Ishido (2015), 'Values and Limitations of the ASEAN Agreement on the Movement of Natural Persons'. ERIA Discussion Paper Series, No. 2015-20. http://www.eria.org/ERIA-DP-2015-20.pdf.

Hill, H. and J. Menon (2014), 'ASEAN Commercial Policy: A Rare Case of Outward-Looking Regional Integration'. ADB Working Paper Series on Regional Economic Integration, No. 144. https://www.adb.org/sites/default/files/publica tion/150385/reiwp-144.pdf.

International Labour Organization (2015), Analytical Report on the International Labour Migration Statistics Database in ASEAN: Improving Data Collection for Evidence-based Policy-making. Geneva: ILO. http://www.ilo.org/asia/publications/ WCMS_431613/lang--en/index.htm.

International Labour Organization (2017), 'Key Indicators of the Labour Market'. http://www.ilo.org/global/statistics-and-databases/research-and-databases/kilm/ WCMS_498929/lang--en/index.htm.

International Labour Organization and Asian Development Bank (2014), ASEAN Community 2015: Managing Integration for Better Jobs and Shared Prosperity. Bangkok: ILO/ADB. https://www.adb.org/sites/default/files/publication/42818/ asean-community-2015-managing-integration.pdf.

Ishido H. (2011), 'Liberalization of Trade in Services under ASEAN+n: A Mapping Exercise'. ERIA Discussion Paper Series, ERIA-DP-2011-02.

Mendoza, D. and G. Sugiyarto (2015), A 'Freer' Flow of Skilled Labour within ASEAN: Aspirations, Opportunities, and Challenges in 2015 and Beyond 2017. http://www.migrationpolicy.org/research/freer-flow-skilled-labour-within-aseanaspirations-opportunities-and-challenges-2015.

Mendoza, D., M.V. Desiderio, G. Sugiyarto, and B. Salant (2016), Open Window, Closed Doors: Mutual Recognition Arrangement on Professional Services in the ASEAN Region. Manila: ADB. https://www.adb.org/publications/open -windows-closed-doors-mras-asean.

Orbeta, Aniceto C. Jr. (2013), 'Enhancing Labor Mobility in ASEAN: Focus on Lower-Skilled Workers'. PIDS Discussion Paper 2013-17.

Organisation for Economic Co-operation and Development (2015), Connecting with Emigrants: A Global Profile of Diasporas 2015. Paris: OECD. www.oecd. org/publications/connecting-with-emigrants-9789264239845-en.htm.

Walmsley, T., A. Aguiar, and A. Ahmed (2013), 'Migration and Growth in East and Southeast Asia'. Policy Research Working Paper 6643. http://documents. worldbank.org/curated/en/133171468002084622/pdf/WPS6643.pdf.

World Bank (2009), World Development Report 2009: Reshaping Economic Geography. Washington, DC: World Bank. http://siteresources.worldbank.org/INTWDRS/ Resources/477365-1327525347307/8392086-1327528510568/WDR09_11_Ch05w eb.pdf.

World Bank (2014), Malaysia Economic Monitor towards a Middle-Class Society. Bangkok: World Bank. http://documents.worldbank.org/curated/en/524381468046 492426/pdf/932370WP0P1528010MiddleClassSociety.pdf. 